\title{
"Cold, stony, dehumanized": Unexpected outcomes of revitalization on the sensory landscape and ambience of public space: The case of Cathedral Street (Ulica Tumska) in Płock
}

This paper shows how changes to the appearance of a street after the revitalization process influence the perception of the street, its sensory landscape and atmosphere. The example of Cathedral Street (Ulica Tumska), the high street in Płock, an average-sized town in Poland, is used to prove that such changes may bring some unexpected results by evoking negative emotions among the residents. The results of the study conducted using focus groups show that the contemporary ambience of Cathedral Street cause negative sensations perceived in four dimensions: touchscape, seescape, soundscape, and smellscape. Those feelings seem to be even stronger tak- ing under consideration positive memories of the street before revitalization. As a result of the negative atmosphere of Cathedral Street and the unpleasant emotions it evokes, the residents' activities conducted on the street are reduced only to fulfilling the most necessary needs. Such conclusion results in a postulate that when designing or redesigning public spaces we should always be aware of the consequences for the ambience of the street and the need to generate positive emotions.

Keywords: high street, ambience, urban experiences, urban sociology, sensory landscape 


\section{Introduction}

The street, understood as a type of public space, is a research topic eagerly undertaken by urban sociology or urban ethnography. There are two distinct ways in which the street can be studied and analyzed. One type of research prioritizes the material and urbanistic aspects, focusing on how the street's materiality organizes social behaviour. This approach also views the street as constituting an element within the urban public space network (Degen, 2018; Hubbard \& Lyon, 2018). The other type of research, however, tends to examine the social life taking place within the street. It also emphasizes the importance of streets in providing individuals and communities with a sense of place and time. This paradigm may be perceived as an element of the broader concept of the sociology of urban experiences, which focuses on "the lived experiences within, and with, places and spaces” (Boer, 2013: 966). Another important part of this approach is analysis of the sensory perception of public spaces - including streets - and their "atmosphere" or "ambiance" (Thibaud, 2011). The atmosphere as understood here is clearly inextricably related to emotions, because it is defined as the potential for spaces to influence feelings (Löw, 2008).

Significantly, this perception of space and its ambience may result in the need to understand that the ambience itself is an important part of the street as a complex social phenomenon. This, in turn, implies that when designing or redesigning the urban space, special attention needs to be paid to the opportunities to influence (i.e., create or renew) the atmosphere. Thibaud (2015: 42) postulates thinking about "a new field of urban intervention" and discusses its meaning: "urban design no longer just focuses on objects but also on what is between the objects. It is no longer just a question of designing buildings or megastructures, but also what surrounds them". Thus, one of the tasks of architects and decision makers is to focus not only on the functional or aesthetic layers, but also on the emotions that are likely to be evoked by changes to a public space. This particularly applies to construction and reconstructions during which the shaping and reshaping of material conditions may, in consequence, exert influence on the atmosphere of the street and evoke negative or positive emotions to its reference.

This paper shows how changes to the appearance of the street after revitalization may influence the perception of the street and its ambience. It demonstrates that the sensory experience of the street evokes negative emotions, and describes how residents tend to juxtapose these negative feelings related the street's current appearance with their positive memories. The case study features Cathedral Street (Ulica Tumska), the high street in Płock, an average-sized town in Poland.

\section{The high street and its changes}

Nick Dines (2018: 953) calls the street a "microcosm of the city" and, being situated in the heart of the population's everyday experience, the street may even serve as a quasi-metaphor for city life itself. Some researchers claim that the street exemplifies the character and the dynamics of the city, which is vividly depicted by Henri Lefebvre (2003: 18): "[The street] serves as a meeting place (topos), for without it no other designated encounters are possible. ... In the street, a form of spontaneous theatre, I become a spectacle, and sometimes an actor. The street is a place where movement takes place, the interaction without which urban life would not exist... The street is a place to play and learn. The street is disorder".

An interesting and significant issue undertaken as part of street research is the "high street". The term is used to describe the main shopping street (or sometimes a conglomerate of several streets), located in the city centre, with its cluster of retail and services (Carmona, 2015). In fact, the high street plays a vital role in medium-sized and small towns because it is connected with the sense of social stability and the permanence of local identity. The traditional high street functions as a communication hub as well as a meeting place, providing convenient access to shopping facilities and service outlets (Griffiths et al., 2008). It can be also treated as a "magical" spot, not only willingly visited by both residents and tourists, creating and facilitating interpersonal contacts, but also generating specific spatial and emotional relationships (Rzegocińska-Tyzuuk, 2008).

However, at some point the high street seems to have lost its importance. This phenomenon is connected to changes in city centres that are usually described as degeneration or decline. These processes have been observed in Western countries since the late 1930s but reached their peak after the 1950s (Robertson, 1995). Urban sprawl (Burchell et al., 1998) and decentralization (Filion \& Bunting, 2006) caused city centres to lose their significance in favour of the suburbs because of relocation of the population, trade, and services outside of city centres (Burayidi, 2001). As a consequence, some city centres began to be perceived not only as unimportant but also as less pleasant neighbourhoods inhabited by disadvantaged communities (like the elderly, immigrants, and excluded people; Neto et al., 2014).

In addition, the commercial role of high streets has been on the decline, whereas a number of alternative points offering a variety of services (financial, entertainment, health, etc.) have been on the rise (Dawson, 1988). This phenomenon has been further compounded by increasing rental costs for commercial space, leading to the outflow of entrepreneurs from the high 
street (Carmona, 2015). As a result, the high street is no longer perceived as the natural social centre of a city.

The decline of the high street - just like the degeneration of the city centres - at some point became both a social and subsequently a political concern. In effect, numerous attempts to revitalize these public spaces were implemented (Anderson, 1964; Carmon, 1999; Seidman, 2004; Hechesky, 2005; Ceretta et. al., 2018). Apart from more general revitalization programs, there were also specific approaches to regenerating the high street. One of the best-known of these is the Main Street America Programme (Internet 1), which addresses the problem in a multidimensional way, focusing on issues such as economic restructuring, organization, promotion, and design (Robertson, 2004). In many cases, however, revitalization processes have not yielded the expected results, such as community regeneration or the social and economic growth of city centres (Kaźmierczak et.al, 2011). Often such processes are only partly effective. The revitalization of the infrastructure and the streets' appearances is the easiest part of the project. Other changes - such as fighting social exclusion, improving the residents' quality of life, or economic growth, are usually much harder to achieve (Nowosielski 2012a, 2012b). Moreover, some of the regeneration programmes turned out to have unexpected effects. Some of them caused gentrification (Cameron, 1992; Miciukiewicz, 2008), some had the effect of spreading economic inequalities (Stern \& Seifer, 2007), and still others made the infrastructure of the city centres and high streets uncomfortable and unpleasant for residents (Gehl, 2010).

\section{Feeling the city}

There is little attention being paid to the effect of revitalization on the ambience of public spaces. Neither do the emotions evoked by the new appearance of the street - either positive or negative - undergo frequent scrutiny. Urban sociology analyses have focused more on the negative consequences of revitalization such as gentrification, rising inequalities, or the inability to activate urban communities. There seems to be a need to pay more attention to the issues of ambience and emotion. Two theoretical frames - proposed by Thibaud and Borer - can be helpful in this matter. Thibaud notes that special attention should be paid to the atmosphere of urban spaces. "Urban space provides numerous ambiances to be felt with all the senses. Whether we think of a lively outdoor marketplace or a dull parking lot, an attractive historical centre or a casual subway station, the very way we relate to those places is based on the sensory experience they involve" (2011: 43). Hence, the street is perceived not only as a place filled with material objects, or even with people, but also a place where everything that surrounds the people therein is perceived through the senses.
This creates certain consequences for a researcher willing to focus on the ambience of the street. Thibaud (2011: 42) claims that in the process of perceiving public space, people do not simply see things as they are but rather feel a kind of "resonance", which lets them experience urban space as a "feeling of self and of the world".

The second frame is based on the sociology of urban experience. As Borer (2013: 969) notes, "[e]ach place in the city can be assessed through its sensory stimuli ... These meanings are layered onto a place, and it is in the very act of embedding these meanings that place identity and place attachment emerge and are shared with others". This remark has two important implications for further research. Firstly, these are the senses that "organize" our experience of ambience and resonance in public space. Therefore, in order to deconstruct them we need to focus on people's sensory experiences within the space. In this context Borer (2013: 969-978) proposes analysis of seescapes, soundscapes, smellscapes, tastescapes, and touchscapes of the city. Those categories somewhat match the classification of "sensual geographies" proposed by Paul Rodaway (1994), who described haptic, olfactory, auditory, and visual geographies.

Seescapes underline the role of sight and vision, which are the most obvious and perceivable ways of experiencing space. Also " $[t]$ he visual aspects of the built environment influence the experience of urban places by giving cues and clues about what types of interactions take place there and between whom" (Borer, 2013: 970). Seescapes focus on elements such as form, colour, volume, size, order, diversity, imageability, and legibility (Wankhede \& Wahurwagh, 2016: 743). It is also important that visual aspects are often taken into account in different strategies for revitalizing public space (Hubbard 1996). Soundscapes pay attention to the fact that the city is full of different sounds, rhythms, and noises of different intensity and volume that come from multiple sources, such as street traffic, public transportation, industrial parks, and people themselves. Certain mixtures of sound are often connected with particular places (Borer, 2013: 971). Smellscapes relate to olfactory perception and its interpretation - especially in the context of acceptable or unacceptable scents that are usually associated with what is socially desirable and undesirable. It is worth noting that in certain cultures - including European ones - a specific phenomenon of odour management can be observed, which is targeted at achieving "scent free" spaces (Waskul \& Vannini, 2008: 55-56). Smellscapes can be defined through different "classification of smell in term[s] of aromatic, fragrant, alliaceous, ambrosial, hircinous, repulsive, nauseous and so on" (Wankhede \& Wahurwagh, 2016: 743) Tastescapes describe the process of experiencing the city through production and consumption of food and drink. They focus on sensual experiences in terms of "sweetness, sourness, saltiness, 
bitterness" (Wankhede \& Wahurwagh, 2016: 743). Touchscapes are perhaps the most difficult dimension to describe because they are not - as it may seem - limited to "the action of fingers feeling the texture of surfaces" (Rodway, 1994: 44) but are connected to more complex experience of moving through spaces and between objects and feeling them with the whole body. Among others they include feelings of "dryness, coldness, roughness and hardness" (Wankhede \& Wahurwagh, 2016: 743). The second consequence is connected with the observation the sensual experiences of the space are not individual but rather shared. As a result, they can be studied not only individually, but also in conditions that offer a perspective on the collective character of these experiences.

\section{Cathedral Street in Płock}

Cathedral Street is located in the historic town centre of Płock a medium-sized industrial town in central Poland inhabited by approximately 120 thousand residents. Its history dates to the early nineteenth century, when, earmarked in the heart of the town (then as Dohm Strasse) it was planned as a connection between two squares in Plock: Canon Square (Rynek Kanoniczy) and New Square (Nowy Rynek; Rydzewska 2009). Although its construction took decades, eventually amounting to half a century, both the way it was designed and its central location contributed to its becoming the high street in Płock. It initially performed crucial functions related to being a vital transportation artery. With time, however, it developed other uses: residential, service, and commercial. The commercial function gained importance at the turn of the twentieth century, when "Cathedral Street tried to aspire to the rank of a shopping centre" (Rydzewska, 2009: 24). With time, it also started to play the role of the cultural and social centre of Płock, arousing positive emotions among the town's residents.

Within the memories of Plock residents that remember the street from the pre-war period, there emerges a picture of a joyful agora that favoured spending time in the open air. It was then that the English Hotel (which no longer exists) served as a place for meetings, tasting homemade wines, and dances. The street was a place where one could "go out" (Luma, 2009). The presence of an art club guaranteed by the colourful bohemia, as well as the opening of the Diocesan Catholic House in 1935, with a cinema and a theatre accommodating 1,500 people, provided entertainment for the less wealthy town residents (Rydzewska, 2009). After the Second World War, the character of the street changed through adaptations to the requirements of the new communist system. New public buildings were built - most of which primarily related to trade (the Centrum department store) and gastronomy (the Piast Catering Complex, later the Hortex Cocktail Bar; Rydzewska, 2009). On one

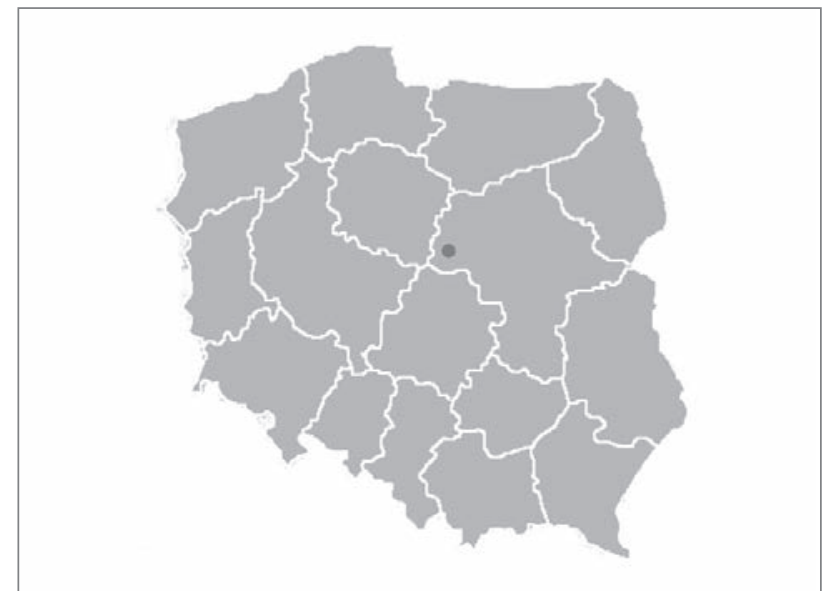

Figure 1: Płock on the map of Poland (source: Internet 2).

hand, the communist authorities transformed the colourful English Hotel into a tailors' cooperative, whereas on the other hand, the Cultural Centre (formerly the Catholic House) on Cathedral Street was still a meeting place for artists and the centre of cultural life with an important place in the form of the Przedwiośnie cinema. Moreover, the profile of the Cathedral Street residents underwent gradual changes, when the wealthy burghers and tenement house owners were replaced by residents of lower socioeconomic status (Luma, 2009). The first street modernization began in the early 1970s. The most important anticipated change was transforming it into a pedestrian precinct with places to relax adorned with flowers and trees; these changes aroused mixed feelings among Płock residents (Rydzewska, 2009). After 1989, the systemic transformation in Poland led to a flourishing of the street's commercial function and strengthening its image as a lively commercial town centre. At the same time, there were new developments appearing that partly replaced the old ruined buildings and corresponded with or matched the original historic buildings (Rydzewska, 2009). The first decade of the twenty-first century coincided with the rapid development of Plock shopping centres. Those openings resulted in the outflow of customers from Cathedral Street, contributing to its decline as a shopping centre in Płock. There followed, however, a simultaneous initiative by the city authorities to modernize the street, with the project completed in 2006. In 2007, the design was granted the main prize in the nationwide competition "Modernization of the Year" and the town authorities embarked on promoting the renovated street under the slogan "City Lounge". A programme to finance tenement revitalization was also launched (Woźniak, 2008). Nevertheless, apart from the changes to the pavement, street furniture, and greenery, further actions were not fully implemented. Moreover, the revitalization activities were not only widely criticized, having evoked strong negative emotions among the town's residents (Woźniak, 2008; Tybura, 2019), but they also failed to 


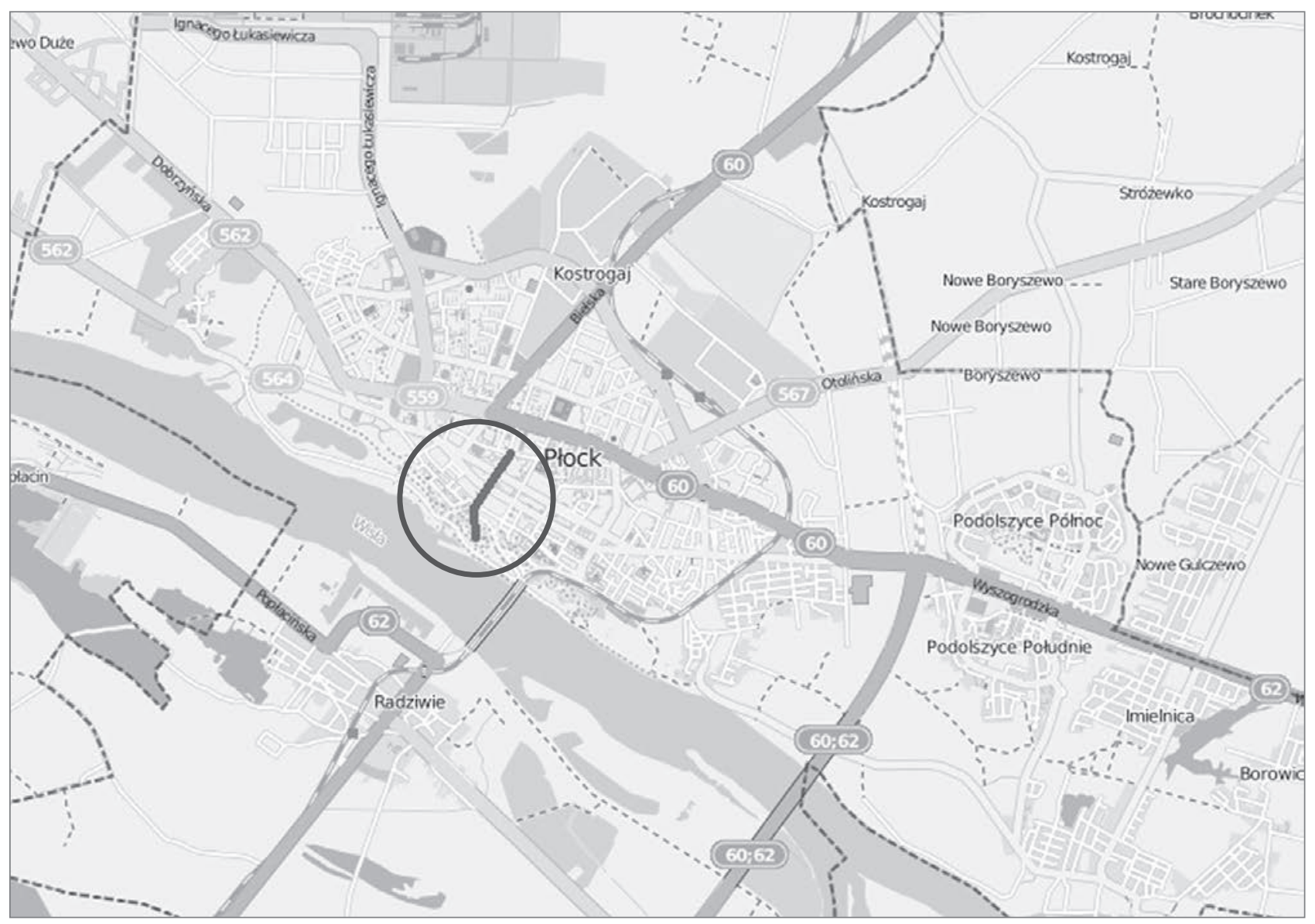

Figure 2: Cathedral Street (Ulica Tumska) in Płock (source: Internet 3).

halt the street's social degeneration and decreasing significance in Płock residents' eyes. In 2012, Cathedral Street was even called Bank Street - because as many as twenty financial institution offices could be counted within the 326-metre-long pedestrian zone. Attention was drawn to the lack of cafes, the few stores and, above all, the shortage of passers-by, all of which resulted in the impression of an empty, deserted street (Woźniak, 2008; Marciniak 2012).

This situation has not particularly changed since then. The street functionally remains just a promenade leading to $\mathrm{Ca}$ thedral Hill (Pol. Wzgórze Tumskie). It seems to have lost its significance as an important place of trade, entertainment and culture (Tybura, 2019). However, it still remains a crucial emotional point of reference. As Ewa Luma (2009: 59) stated while presenting the elderly residents of Plock's experiential histories of Cathedral Street: "Cathedral Street has an important yesterday, and ahead of us, we hope, is the splendour of tomorrow. Will Cathedral Street be the city lounge? The next centuries will show .... The people passing along the street are her life. The street character consists of numerous elements: its buildings; houses, courtyards, alleys, the windows of the flats where people live. Residents are like the bloodstream of every town.
The houses themselves are only its external image, whereas the street itself is designated by people and their associated emotions."

\section{Research method and data}

The paper is based on an analysis of the data gathered in 2018 from two focus groups (FGs) comprising the residents of Płock. Each focus group included eight individuals. Purposive sampling based on the maximum differentiation criterion was applied. The people chosen for the study were of various ages, educational backgrounds, and professions. Another criterion of sampling was place of residence: respondents from different parts of Płock took part in the focus groups. Each of the FGIs took place in the building of Mazovian State University, which is not located in the city centre but in one of the housing estates of Płock. The first focus group lasted for one hour and twenty-six minutes, and the second one hour and forty minutes.

The FGI scenario consisted of six topics, including the projection question on the impressions felt while imagining walking on today's Cathedral Street. The first block of questions was treated as a "warm-up" and concerned mostly facts about our 


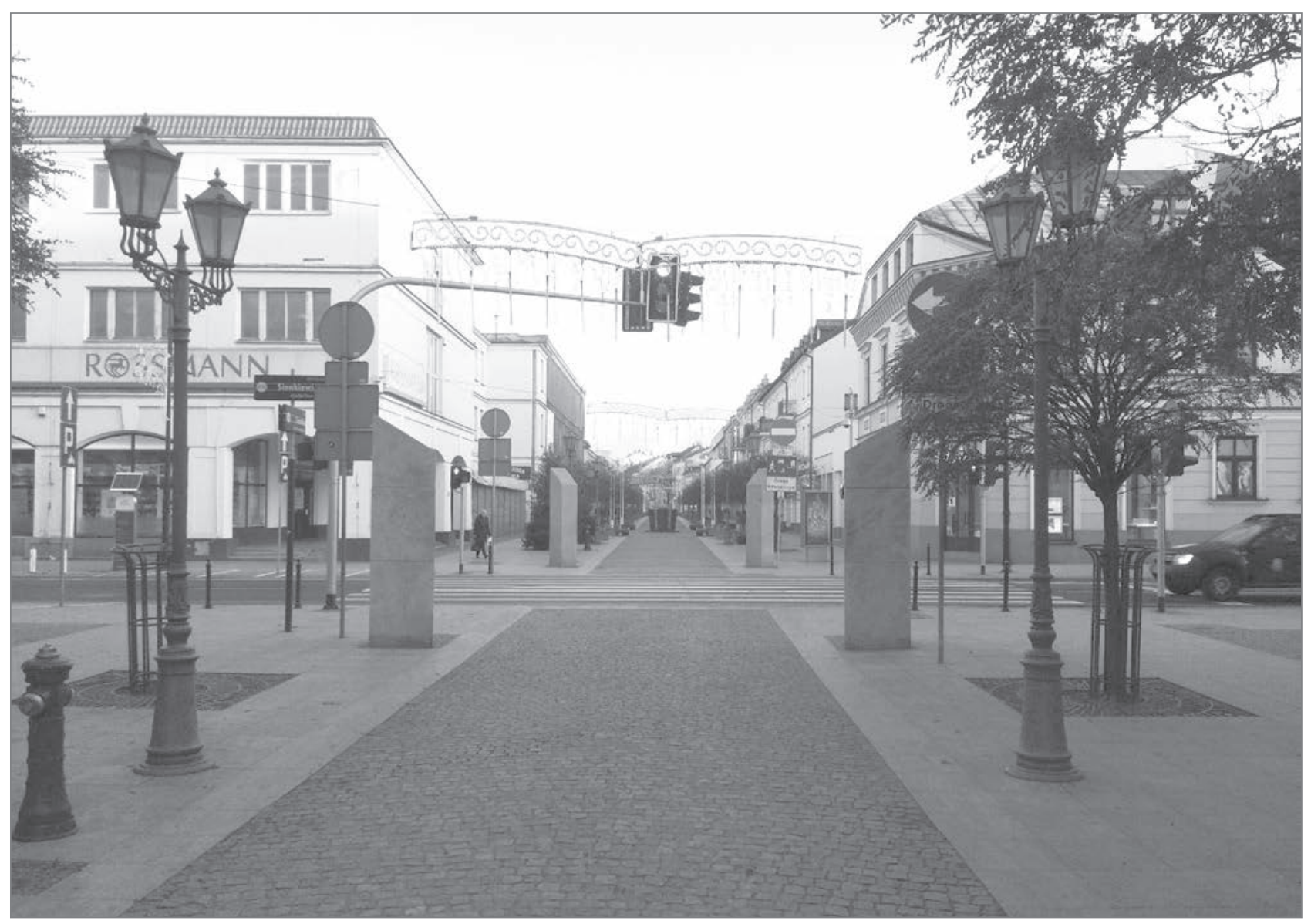

Figure 3: Stony Cathedral Street (photo: Michał Nowosielski).

respondents: their socio-demographic background, place of residence in Płock, and relationship with Cathedral Street. The second block of questions was based on projection techniques that were supposed to help to capture the respondents' emotions towards the street and its ambience, and the resonance they experienced. As a verbal stimulus, the moderator asked the respondents to close their eyes and imagine that they were on Cathedral Street. The respondents were asked to visualize themselves walking along the street and then to describe their feelings and impressions. It turned out that the respondents' reactions to this applied projection technique was enthusiastic, and their answers supplied interesting data concerning their perception of Cathedral Street's ambience. The third topic raised by the study dealt with everyday contact with Cathedral Street. The respondents were asked to describe how often they were on Cathedral Street and for what reason, or - if they did not visit it - why not. The next topic concerned events organized on Cathedral Street and their perception. The fifth block of questions dealt with strong and weak sides of the street. The point here was to find the positive and negative elements of Cathedral Street's social perception. The last issue that was raised during the FGI concerned an imagined, perfect Cathedral Street. The respondents were asked to describe what the "ideal Cathedral Street" would look like.
This article concentrates mostly on issues concerning the perception of Cathedral Street and its ambience. Therefore, its analyses focus on sensory experiences of the street divided into four categories as defined by Borer (2013), memories of feelings of the past Cathedral Street, and consequences of the revitalization process for the street's ambience. Focus groups were chosen as a research technique because they are a tool that allows greater respondent involvement. Group processes that take place during a focus group make it easier for respondents to open up to others and make contact. It offers researchers the opportunity to encourage respondents to be more expressive and to share their feelings and emotions (Gawlik, 2012). It may also provide an opportunity to discuss shared experiences and emotions. Obviously, this can only be achieved if the issues raised do not apply to highly problematic or intimate issues.

\section{Results}

The questions about their perception of Cathedral Street's ambience proved highly effective in obtaining data specifying the respondents' feelings. Many of the answers and the discussions stemming from them referred to sensual, almost bodily impressions. Following Borer's concept (2013), they can be or- 


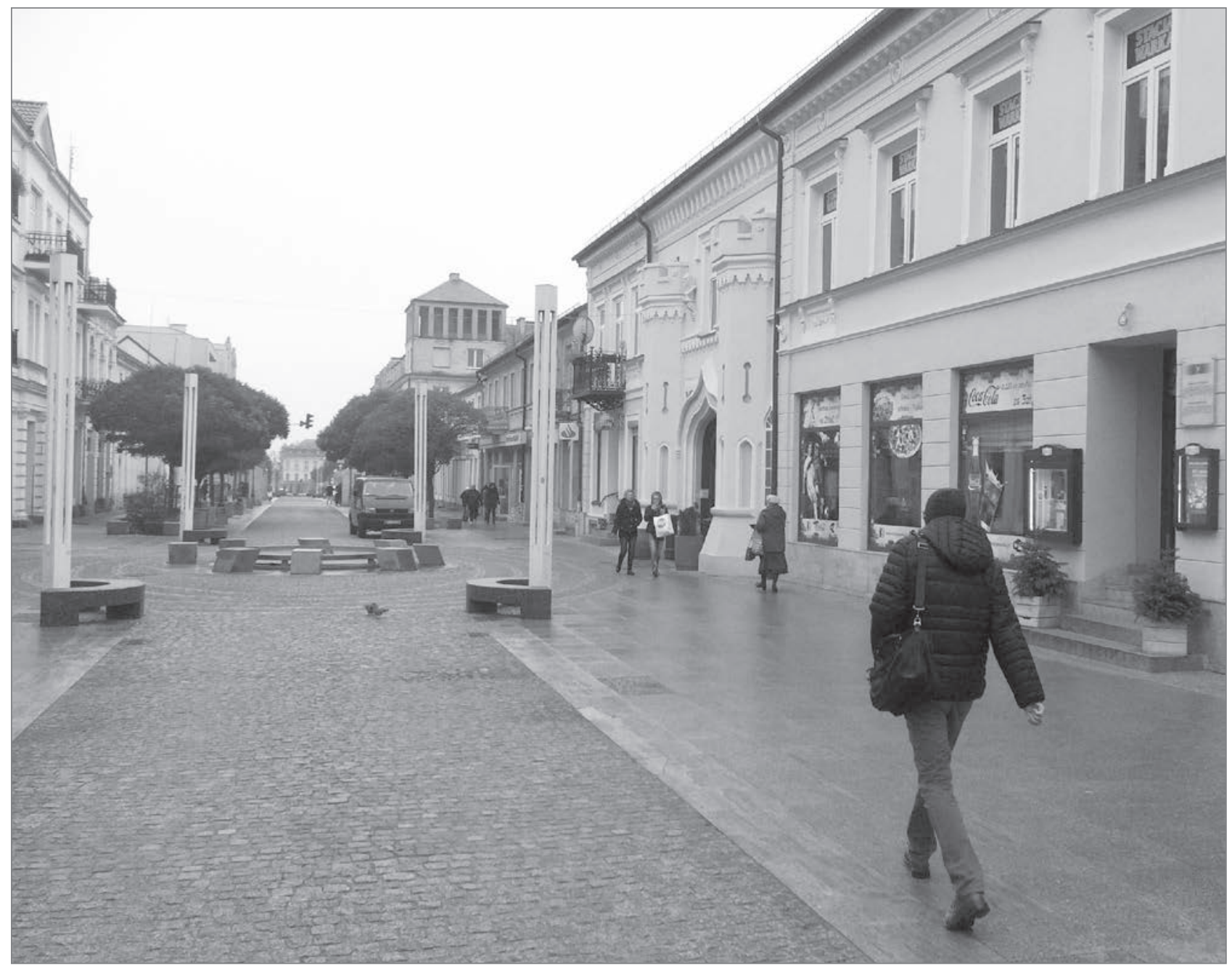

Figure 4: Diverse surface and pedestrians using sidewalks on Cathedral Street (photo: Michał Nowosielski).

ganized in four dimensions: touchscape, seescape, soundscape, and smellscape. One of the categories - tastescape - was not part of the study.

The respondents' statements below are coded as follows: when a single statement is provided it is coded with the number of the focus group and the number of respondent (e.g., FG1R4); when an exchange of views between more than one respondent is provided, each line is assigned the respondent's number and the whole conversation the interview number. The moderator's questions are coded with the number of the focus group and the letter M (e.g., FGI2M).

\subsection{Touchscape}

The sensation mentioned most often was the feeling of coldness. This association gave the respondents the impression of acute discomfort:

FG1R4: However unspectacular it may sound, [I feel] cold and emptiness.
FG2R7: I feel a cold atmosphere.

FG1R7: And that's interesting, because I felt cold too. The first word I thought was "cold".

During the discussions, the respondents further described the sources of that feeling. Many of them pointed out that Cathedral Street's coldness stemmed from its material makeup, namely from the materials it is paved with, and from the form and materials of the street furniture. In their descriptions the respondents indicated the prevalence of stone materials used throughout Cathedral Street to be to blame.

FG2M: Coldness? Why does it appear? Where does it come from?

R5: I think the materials from which the street was made.

R2: Yes!

R5: . . made of. It's exactly as I say. This pavement ....

R1: These stone benches.

R6: Everything's just so cold.

R1: Glass advertising columns .... Is that what you're talking about?

R5: Yes. Everything is so .... There is no spontaneity. 

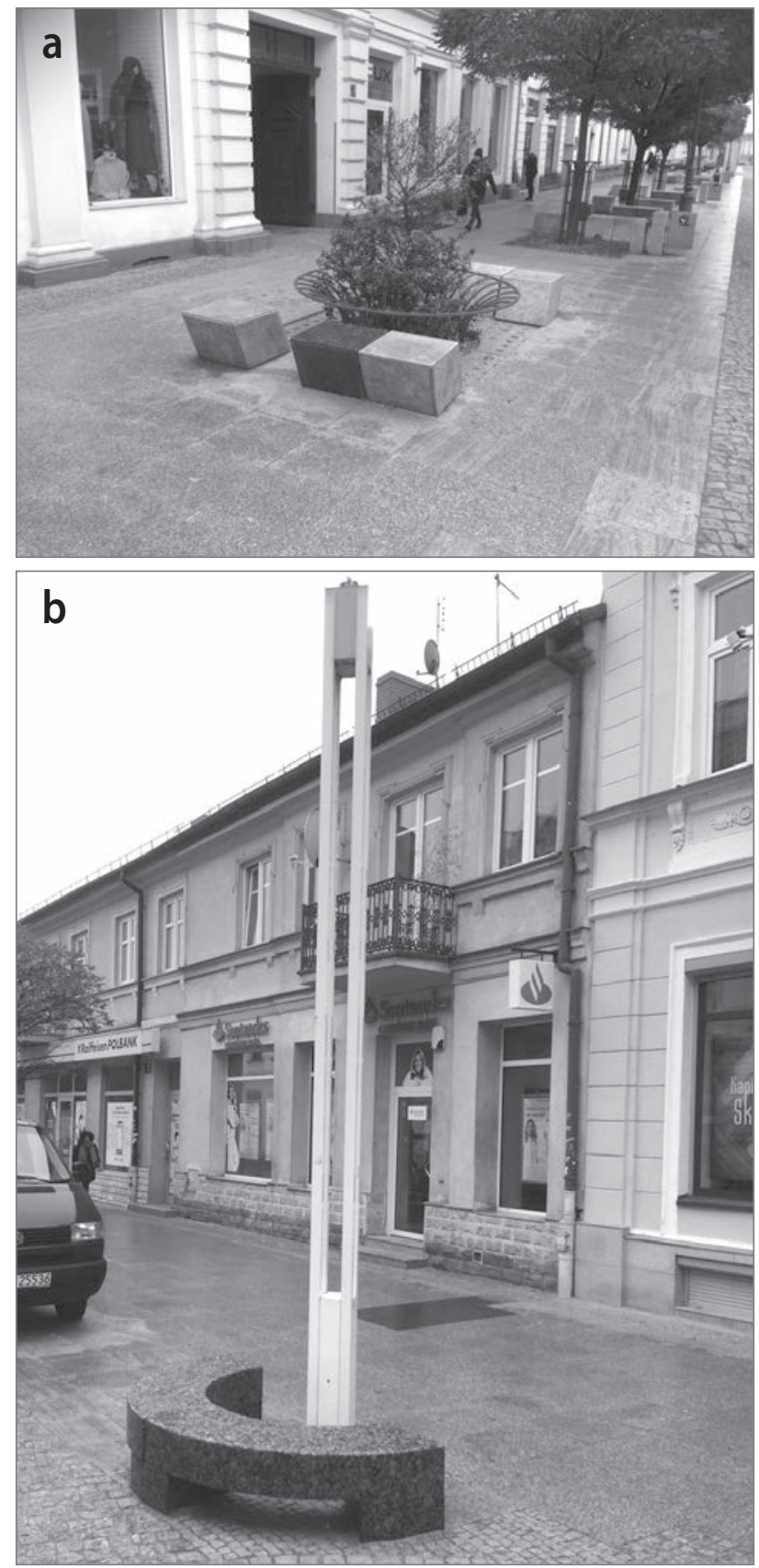

Figure 5a, 5b: Benches on Cathedral Street (photo: Michał Nowosielski).

The street furniture and the pavement seemed to evoke especially strong sensations and feelings among the respondents. One of the elements that drew particular attention was the surface of the promenade, which is diverse: with smooth slabs on the sides and uneven paving stones in the centre. Apart from the sense of coldness described above it was also seen as uncomfortable and dysfunctional. What is important the respondents described their experiences using expressions highlighting their sensual feelings of slipperiness or roughness.

FG2R4: The [surface] they put there, it's bad. Simply uneven. When I'm in a hurry, for example, from the bus to work, and
I'm going fast, it's hard on those paving stones. Especially when it's slippery.

M: There are different zones.

R2: Yes. And when walking I chose ....

R1: The sides. It's more comfortable there.

R2: That's right, because there in the middle ... there are so many stones. I ride my bike down the middle, I admit, because there are just fewer people.

R7: [The sides are] slippery in winter. In the winter, it's better to stick to the middle of the road.

Another problem the respondents noted was the street furniture, which is also perceived as stony and cold. Those sensual experiences translate into the way the street furniture is perceived as not fulfilling its role. The most frequently discussed examples were the benches, which should be places to sit, rest, and talk, but which the respondents believed were not only not cosy and uncomfortable, but even dysfunctional. They were described as "unfriendly", amplifying the cold in the winter and the heat in the summer.

FG1R1: It's bare. There is just stone, unfriendly anyway, because those seats are ....

R7: Completely dysfunctional.

R2: They don't encourage you to sit either in the summer or winter, because it's either too warm or too cold.

\subsection{Seescape}

In addition to cold, another feeling the respondents described was the sensation of hollowness and being deserted. Most of them stated that in their imaginary picture of the street there was no one around them.

FG1R5: Emptiness. I didn't see anyone passing by there, unfortunately.

FG2R1: There are no people on Cathedral Street.

Interestingly enough, some of the respondents did not connect the emptiness with the social factors (lack of people) but rather with the architectural shape of the street. Once again there was a theme of being stony, accompanied by remarks on the lack of trees and the general impression of Cathedral Street being hollow.

FGI1R4: A stone desert, this is my association.

\subsection{Soundscape}

The respondents often associated these two sensations - the feelings of cold and emptiness - somehow trying to explicate one with the other. In addition, they also added another im- 


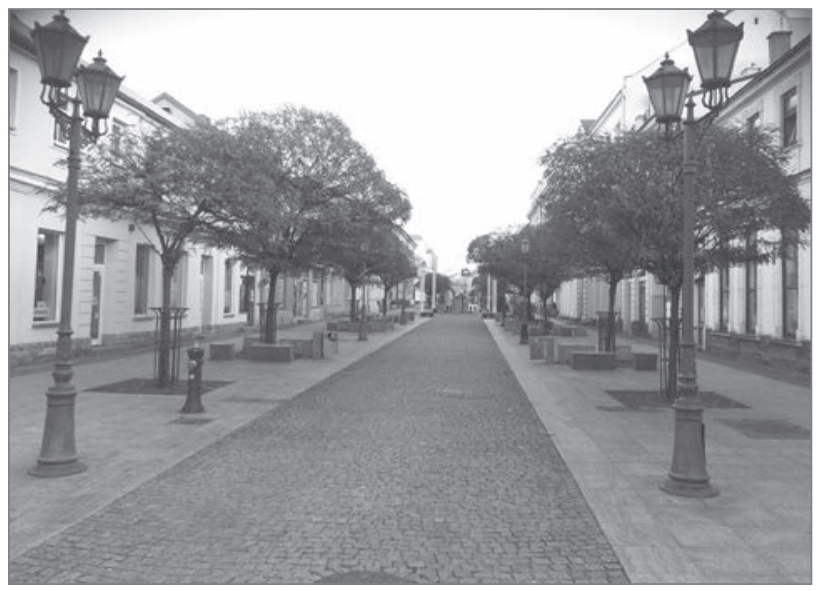

Figure 6: Deserted Cathedral Street (photo: Michał Nowosielski).

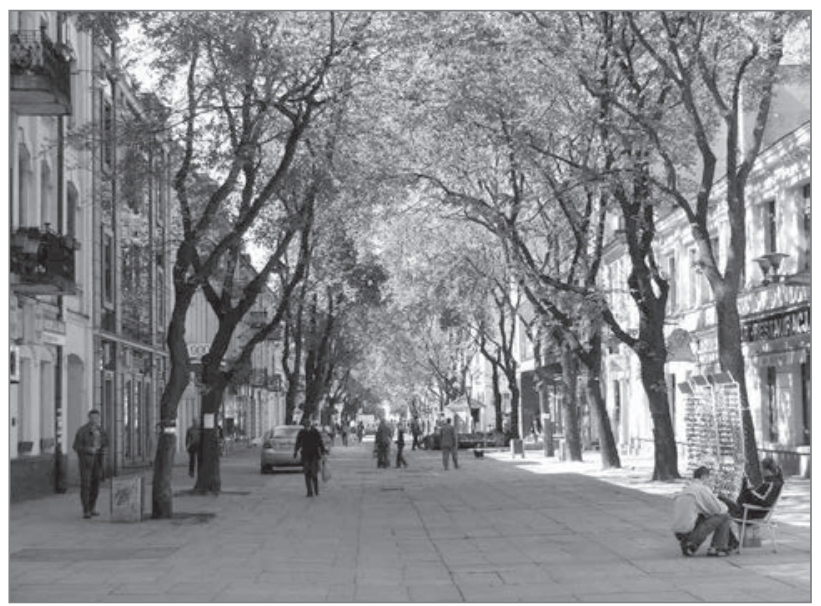

Figure 7: Cathedral Street before revitalization (photo: Mariusz Kucharczyk).

pression strongly affecting the ambience of the street: silence. In fact, the respondents did not refer to quietness but rather to the lack of ordinary street noises.

FG2R4: I think that the coldness of the street ... I mean, this coldness stems from the fact that there is just a lack of people, that it's so empty, that it's such a deserted street when you go from one end to the other.

FG2R7: Probably it's the most important of all .... In general, there's a shortage of people and a lack of life and street noise, which would immediately make it more pleasant, somehow.

\subsection{Smellscape}

The last - and least mentioned - sensual experience was associated with the sense of smell. Some of the respondents claimed that when they imagined walking on Cathedral Street they smelled an unpleasant odour of the smoke from the furnaces used to heat some tenements.

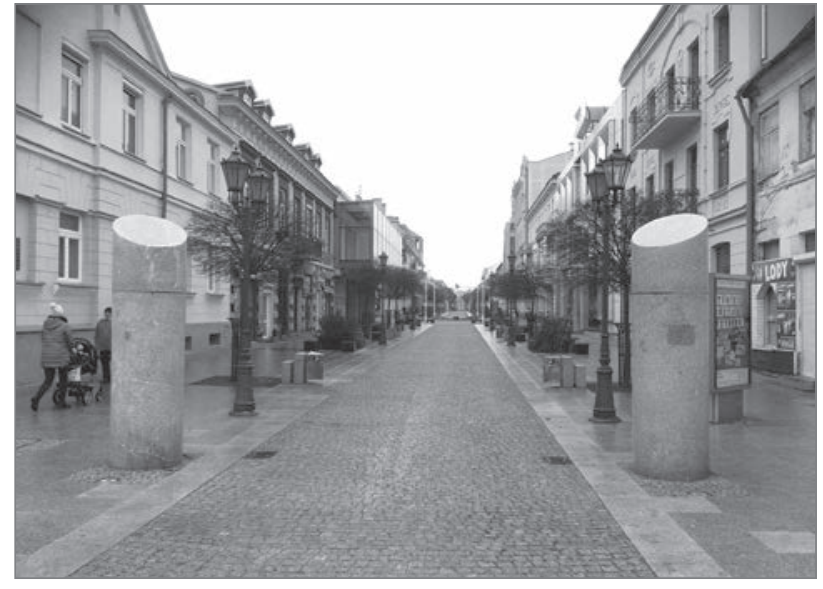

Figure 8: View of Cathedral Street (photo: Michał Nowosielski).

FG2R5: Choking smoke from chimneys. Well, this is such a very unpleasant feeling.

\subsection{Ambience of Cathedral Street in memories}

In their statements, the respondents sometimes compared today's unfriendly sensations with their memories of the times when their feelings were much more pleasant. They often juxtaposed coldness with warmth and emptiness with the pleasant feeling of being together with other people. In one of the statements, the respondent compared the difference between today's Cathedral Street and the old one - before revitalization - to the difference between something alive and dead.

FG1R4: I still remember that old Cathedral Street. I remember a street that had a completely different face. That is, it was ... obviously neglected, it didn't look great. A little bit backward, a bit from a different era, but it had its own atmosphere. It had a completely different atmosphere. There were big, nice, green, spreading trees. There were niches with benches where you could sit down and people would buy either a cake or an icecream, and just stop there, or sit down to talk. Well, different people, not only intellectuals after all, but also ordinary people who lived nearby, and that Cathedral Street simply lived.

When asked about the moment of change, the respondents always pointed to the revitalization of Cathedral Street, claiming that the renovation of the promenade changed its character and made it look unfriendly to the passers-by. Interestingly, the new - more aesthetic - form of the street turned out to be less emotionally accepted. In their statements the respondents often highlighted that the whole concept of Cathedral Street renovation was more one of a single designer's artistic vision than an answer to social needs and expectations.

FG1R2: I was shocked when I saw Cathedral Street after the renovation. Did you notice? Once Cathedral Street ... was full of trees. It wasn't really possible to see... 
Table 1: Experienced sensations on Cathedral Street and types of sensory landscape.

\begin{tabular}{lllll}
\hline \multicolumn{4}{l}{ Type of sensory landscape } & \\
\hline Description of sensation & Touchscape & Seescape & Soundscape & Smellscape \\
\cline { 2 - 4 } & Cold & Empty & Silence & Smokiness \\
\hline Slippery & Hollow & Soundlessness & Smelly/Stinky \\
\hline Rough & Deserted & & \\
\hline Unfriendly & & & \\
\hline
\end{tabular}

R4: A view of the street ...

R2: Yes, a view. And at some point after the renovation I looked and saw that there wasn't anything left.

FG1R6 That is, I think, that here is the problem of the approach of the person who planned it ... it's like furnishing a flat in a very modern style, but he didn't do it for everyone. I think he did it only for himself, to fulfil the vision he had in his mind. Okay, it helped him to pursue his professional life and he actually got the rewards for it, but it hasn't helped anyone else.

Statements describing the negative perception of the renovation were usually the introduction to the more general remarks regarding whom the street and its renovation should serve. In those parts of the discussion, again, respondents made references to their strong negative emotions evoked by the revitalization outcomes. Negative motions evoked by Cathedral Street after revitalization seem to create a specific atmosphere of being dehumanized or unfriendly or even "not for life". It is an important rejection factor, causing people not to use it in any other way than necessary. As a result, the function of Cathedral Street is reduced to a connection between other streets and spaces.

FG1R4 But whom should it serve? The town is to serve its people. The town is for us and it should be functional, it should be friendly, it should encourage spending time in this open space. In the meantime, there is nothing like that, it even repels people, this Cathedral Street pushes you back. As they say, just go, go through it and pass it.

FG1R4 Cathedral Street is simply cold, stony, dehumanized, unfriendly for people, for passers-by . . . not for life.

FG1R7 The street's just a passageway.

\section{Discussion}

Thibaud (2015: 42), postulating about the focus of design on emotions and ambience, writes: "In brief, our purpose is to transform not only the world of the objects built but also the world of the air and the perceptible atmosphere." Such a task, however, requires focusing on the emotions that are evoked in and by public spaces. It may be especially difficult in the case of renovating the public space - especially one of such great social and emotional importance as the high street, where the architect needs to deal not only with the decision makers' expectations but also with the previously-held residents' views and feelings gathered over their years of personal experience.

The FG analysis shows that Cathedral Street evokes strong sensual feelings of respondents in all four analyzed dimensions: touchscape, seescape, soundscape, and smellscape (see Table 1). In case of the touchscape, the respondents reported sensations of coldness, referring to the general atmosphere of the street, as well as to its specific elements. This coldness is accompanied by such feelings as the slipperiness/roughness of the pavement or unfriendliness of the street furniture. As for the seescape, respondents talked about the notion of emptiness, comparing Cathedral Street to a hollow desert. Cathedral Street's soundscape has been described with metaphors of the lack of normal street noise, and the smellscape with the sensation of the odour of smoke.

All four dimensions make the ambience of today's Cathedral Street and its sensory landscape "cold, stony, and dehumanized". Those sensations become even more striking when compared to the memories of Cathedral Street being warm, crowded, and full of positive emotions. It seems that what we witness is a confirmation of Paul Rodaway's (1994) observation that perception may not only mean reception of information but also "mental insight" - a feeling made of sensory information amalgamated with memories and expectations. This clash between positive images of the past Cathedral Street and rather negative experiences with the contemporary appearance of the street makes the perception of the sensory landscape so strikingly distasteful - possibly more distasteful than the objective form of the street would suggest. The case of Cathedral Street in Płock also shows how renovation aimed at the revitalization of an important public space brings unexpected and unwanted results by irreversibly disrupting the street atmosphere. The change of the space brought about by the revitalization process evokes strong emotions in the residents, who describe their feelings with severe sensual impressions. Experiencing Cathedral Street thus induces a negative resonance among Płock residents. 
The perception of the street's ambience and the residents' feelings show that consequences are not exclusively reduced to psychological or emotional dimensions. As Kalyani Wankhede and Amit Wahurwagh (2016) note, both positive and negative sensory experiences of urban spaces strongly influence the quality of public places. They may result in changes to how people perceive themselves in this space (e.g., in terms of belonging or not belonging, the feeling of being in the right or wrong place, etc.). They may also have an impact on questioning ways to make use of the space. It seems that when the street atmosphere is negative and the emotions evoked are unpleasant, it changes the residents' activities conducted on the street, reducing its usage only to fulfilling the most necessary needs. Using Jan Gehl's (2010) metaphors, one might say that Cathedral Street is used only for necessary/functional activities - those in which people are forced to use Cathedral Street as a passageway to other destinations: other streets or important spaces. At the same time, other activities (optional or recreational activities, such as walks, and social activities undertaken in the presence of or in cooperation with others, such as group walks and having fun together) of a more voluntary character are seriously limited.

\section{Conclusion}

It can be concluded that, when designing or redesigning public spaces one should always be aware of the rule that well-designed public spaces should induce people to stay among others outside their homes by generating positive emotions, whereas badly designed places can deter and discourage people from spending time together, which in turn evokes highly negative feelings. The study findings prove that sensual perceptions are crucial in this process. It can therefore be postulated that when creating a revitalization or renewal plan, one should use sensory studies that would take into consideration all the senses, combined with residents' memories and expectations. Such sensory landscape studies might be helpful in decision-making (Battistini \& Mondino, 2017; El-Sayyad, 2019). At the same time, it is important to mind the gap between the typical measures used by professionals (like architects) - based on aesthetic and functional criteria - and "popular measures" applied by the residents, and focus more on feeling the space and resonating with it. These study findings show that both should be taken into consideration. Previous studies show that there are revitalization processes that have succeeded in considering the important role of senses (Degen, 2004; Brown, 2012; Henshaw, 2013).

The case presented here shows that ambience, emotions, and senses may be useful research measures of the sociology of urban experiences, which help to understand how people "resonate" with the public space. There is, however, a need to conduct broader studies using more examples and more research techniques. Although the FGI proved to be an effective tool, in further research it should be supported by the use of other techniques including specific methodology based on conducting sense-walks (smell-walks, sound-walks, etc.), preparing sense-notes describing perception and interpretation of perceived feelings, and finally creating sense-maps (ElSayyad, 2019). Such a procedure could be a source of important information on the sensual experience of a public space and provide guidance for how to shape or reshape it.

Michal Nowosielski

Mazovian State University in Płock, Płock, Poland

E-mail:m.nowosielski@mazowiecka.edu.pl

Agnieszka Nowosielska

Mazovian State University in Płock, Płock, Poland

E-mail:a.nowosielska@mazowiecka.edu.pl

\section{Acknowledgments}

This work was funded as part of the research project "Tumska na nowo - badania", commissioned by the City of Płock Office and carried out at Mazovian State University.

\section{References}

Anderson, M. (1964) The federal bulldozer. Cambridge, MA, MIT Press.

Battistini, E. \& Mondino, M. (2017) For a semiotic multisensorial analysis of urban space. The case of Ballaro and Vucciria markets in Palermo. Punctum, 3(1), pp. 12-26.

Brown, A. L. (2012) A review of progress in soundscapes and an approach to soundscape planning. International Journal of Acoustics and Vibrations, 17(2), pp. 73-81.

Borer, M. I. (2013) Being in the city: The sociology of urban experiences. Sociology Compass, 7(11), pp. 965-983. DOI: 10.1111/soc4.12085

Burayidi, M. A. (2001) Introduction: Downtowns and small city development. In: Burayidi, M. A. (ed.) Downtowns: Revitalizing the centers of small urban communities, pp. 1-6. New York, Routledge. DOI: $10.4324 / 9781315889436$

Burchell, R., Shad, N., Listokin, D., Phillips, H., Downs, A., Seskin, S., et al. (1998) The costs of sprawl - revisited. Transit cooperative research program report 39. Washington DC, National Academy Press.

Cameron, S. (1992) Housing, gentrification and urban regeneration policies. Urban Studies, 29(1), pp. 3-14. DOI: 10.1080/00420989220080011

Carmon, N. (1999) Three generations of urban renewal policies: Analysis and policy implications. Geoforum, 30(2), pp. 145-158.

DOI: $10.1016 / \mathrm{s} 0016-7185(99) 00012-3$

Carmona, M. (2015) London's local high streets: The problems, potential and complexities of mixed street corridors. Progress in Planning, 100, pp. 1-84. DOI: 10.1016/j.progress.2014.03.001

Cerreta, M., Daldanise, G. \& Sposito, S. (2018) Culture-led regeneration for urban spaces: Monitoring complex values networks in action. Urbani izziv, 29(Special edition), pp. 9-28.

DOI: 10.5379/urbani-izziv-en-2018-29-supplement-001

Dawson, J. A. (1988) Futures for the high street. The Geographical Journal, 154(1), pp. 1-12. 
Degen, M. (2018) Timescapes of urban change: The temporalities of regenerated streets. The Sociological Review, 66(5), pp. 1074-1092. DOI: 10.1177/0038026118771290

Degen, M. (2004) The power of sensuous ideologies in framing the city. Paper presented at the 11th International Planning History Conference "Planning Models and the Culture of Cities", 14-17 July, Barcelona, Spain. Typescript. Available at: https://www.academia.edu/17032481/ The_power_of_sensuous_ideologies_in_framing_the_city (accessed 15 Feb. 2020).

Dines, N. (2018) What's in a word? Contextual diversity, urban ethnography and the linguistic limits of the street. The Sociological Review, 66(5), pp. 952-967. DOI: 10.1177/0038026118771289

El-Sayyad, N. (2019) Role of sensory maps in cultural planning to shape the future of deteriorated heritage sites. Paper presented at the 8th International Conference"ARCHCAIRO8:" Building the Future "Now" - Rights to Better Living, Architecture and Contexts, 8-10 April, Cairo, Egypt. Typescript. Available at: http://www.academia.edu/ download/59005500/ROLE_OF_SENSORY_MAPS_IN_CULTURAL_PLANNING_TO_SHAPE_THE_FUTURE_OF_DETERIORATED_HERITAGE_ SITES20190423-122828-1 kz2xcf.pdf (accessed 15 Feb. 2020).

Filion, P. \& Bunting, T. (2006) Understanding twenty-first century urban structure. In: Bunting, T. \& Filion, P. (eds.) Canadian cities in transition, pp. 1-23. Don Mills, Oxford University Press. DOI: 10.1080/00420989220081411

Gawlik, K. (2012) Badania fokusowe. In: Jemielniak, D. (eds.) Badania jakościowe. Metody i narzędzia, pp. 131-162. Warsaw, Wydawnictwo Naukowe PWN.

Gehl, J. (2010) Cities for the people. Washington DC, Island Press.

Griffiths, S., Vaughan, L., Haklay, M. \& Jones, C. E. (2008) The sustainable suburban high street: A review of themes and approaches. Geography Compass, 2(4), pp. 1155-1188. DOI: 10.1111/j.1749-8198.2008.00117.x

Hechesky, L. (2005) Return to main street: An assessment of the main street revitalization program. Master's thesis. Huntington, WV, The Graduate College of Marshall University.

Henshaw, V. (2013) Urban smellscapes: Understanding and designing city smell environments. New York, Routledge. DOI: 10.4324/9780203072776

Hubbard, P. (1996) Urban design and city regeneration: Social representations of entrepreneurial landscapes. Urban Studies, 33(8), pp. 1441-1461. DOI: 10.1080/0042098966745

Hubbard, P. \& Lyon, D. (2018) Introduction: Streetlife - the shifting sociologies of the street. The Sociological Review, 66(5), pp. 937-951. DOI: $10.1177 / 0038026118771281$

Internet 1: https://www.mainstreet.org/ (accessed 3 Feb. 2020).

Internet 2: https://pl.wikipedia.org/wiki/Płock (accessed 3 Feb. 2020).

Internet 3: https://pl.wikipedia.org/wiki/Ulica_Tumska_w_Płocku (accessed 3 Feb. 2020).

Kaźmierczak, B., Nowak, M., Palicki, S. \& Pazder, D. (2011) Oceny rewitalizacji. Studium zmian na poznańskiej Śródce. Poznań, Wydawnictwo Wydziału Nauk Społecznych UAM.

Lefebvre, H. (2003) The urban revolution. Minneapolis, University of Minnesota Press.

Löw, M. (2008) The constitution of space: The structuration of spaces through the simultaneity of effect and perception. European Journal of Social Theory, 11(1), pp. 25-49. DOI: 10.1177/1368431007085286

Luma, E. (2009) Tumska - drugie „imię" naszego miasta. In: Rydzewska, B., Luma, E. \& Kras, A. (eds.) Dwa wieki Tumskiej. Wczoraj, dziś, jutro, pp. 59-68. Płock, Książnica Płocka.
Marciniak, J. (2012) Galerie wykończyły Tumskq. Tygodnik Płocki. Available at: https://tp.com.pl/artykul/galerie-wykonczyly-tumska/687915 (accessed 15 Sept. 2019).

Miciukiewicz, K. (2008) Półwiejska Street in transition: Gentrification or revitalisation? In: Nowak, M. \& Nowosielski, M. (eds.) Declining cities/ Developing cities: Polish and German perspectives, pp. 113-128, Poznań, Instytut Zachodni.

Neto, L., Pinto, N. \& Burns, M. (2014) Evaluating the impacts of urban regeneration companies in Portugal: The case of Porto. Planning Practice \& Research, 29(5), pp. 525-542. DOI: 10.1080/02697459.2014.973685

Nowosielski, M. (2012a) Between area-based initiatives and community-development programmes. The example of the Soziale Stadt Programme. Sociologija i Prostor 194(3), pp. 309-325.

DOI: $10.5673 /$ sip.50.3.2

Nowosielski, M. (2012b) Challenging urban exclusion? Theory and practice. Polish Sociological Review, 179(3), pp. 369-383.

Rodaway, P. (1994) Sensuous geographies: Body, sense, and place. London, Routledge.

Robertson, K. (2004) The main street approach to downtown development: An examination of the four-point program. Journal of the Architectural and Planning Research, 21(1), pp. 55-73.

Robertson, K. A. (1995) Downtown redevelopment strategies in the United States: An end-of-the-century assessment. Journal of the American Planning Association, 61(4), pp. 429-437. DOI: $10.1080 / 01944369508975655$

Rydzewska, B. (2009) Dwa wieki Tumskiej. Szkic z dziejów zabudowy ulicy. In: Rydzewska, B., Luma, E. \& Kras, A. (eds.) Dwa wieki Tumskiej. Wczoraj, dziś, jutro, pp. 5-33. Płock, Książnica Płocka.

Rzegocińska-Tyżuk, B. (2008) Fenomen ulicy głównej jako "serca miasta" - wybrane przykłady. Czasopismo Techniczne, 4-A, pp. 115-125.

Seidman, K. (2004) Inner-city commercial revitalization: A literature review (working paper). Boston, Massachusetts Institute of Technology.

Stern, M. J. \& Seifert, S. C. (2007) Culture and urban revitalization: A harvest document. Culture and community revitalization: A collaboration. 7. Available at: http://repository.upenn.edu/siap_revitalization/7 (accessed 12 Feb. 2020).

Thibaud, J.-P. (2011) The three dynamics of urban ambiances. In: LaBelle, B. \& Martinho, C. (eds.) Sites of sound: Of architecture and the ear, pp.43-53. Berlin, Errant Bodies Press.

Thibaud, J.-P. (2015) The backstage of urban ambiances: When atmospheres pervade everyday experience. Emotion, Space and Society, 15, pp. 39-46. DOI: 10.1016/j.emospa.2014.07.001

Tybura, J. (2019) Czy lubi pan(i) Tumską? Dlaczego aż co 10. płocczanin bywa na niej nie częściej niż raz w roku? Gazeta Wyborcza - Płock, 8 Feb. 2019. Available at: http://plock.wyborcza.pl/ plock/7,35681,24442425,czy-lubi-pan-i-tumska-dlaczego-az-co-10-plocczanin-bywa-na.html (accessed 15 Sept. 2019).

Wankhede, K. \& Wahurwagh, A. (2016) The sensory experience and perception of urban spaces. International Journal on Emerging Technologies, 7(1), pp. 741-744.

Waskul, D. D. \& Vannini, P. (2008) Smell, odour, and somatic work: sense-making and sensory management. Social Psychology Quarterly, 71(1), pp. 53-71. DOI: 10.1177/019027250807100107

Woźniak, H. (2008) Ulica Tumska: najładniejsza i najstraszniejsza. Gazeta Wyborcza - Płock, 18. Sept. 2008. Available at: http://plock.wyborcza.pl/ plock/1,35681,5710056,Ulica_Tumska_najladniejsza_i_najstraszniejsza. html (accessed 15 Sept. 2019). 